\title{
Article \\ Effects of Changes in ENSO on Seasonal Mean Temperature and Rainfall in Nigeria
}

\author{
Opeyemi R. Salau *, Ayodele Fasuba, Kelvin A. Aduloju, Gbenga E. Adesakin \\ and Adetona T. Fatigun
}

Received: 27 May 2015; Accepted: 5 January 2016; Published: 22 January 2016

Academic Editor: Monica Ionita-Scholz

Department of Physics, Faculty of Science, Ekiti State University (EKSU), Ado-Ekiti, Nigeria; fasubadj@gmail.com (A.F.); adulojukelvin@yahoo.com (K.A.A.); adesakingbenga@gmail.com (G.E.A.); linkfashy@yahoo.com (A.T.F.)

* Correspondence: o.salau@t-online.de; Tel.: +234-816-371-7664

\begin{abstract}
This study investigates the effects of El Niño/Southern Oscillation (ENSO) on temperature and rainfall in Nigeria. The persistent rise in population with more demands for rainfall and water supply in Nigeria requires a better understanding of the impacts of ENSO (La Niña, El Niño) induced changes on the precipitation patterns under future climate conditions. Thus, we compared the sea surface temperature (SST) from the ENSO regions of the Tropical Pacific Ocean (Niño $3\left(150^{\circ} \mathrm{W}-90^{\circ} \mathrm{W}\right.$, $\left.5^{\circ} \mathrm{S}-5^{\circ} \mathrm{N}\right)$ and Niño $\left.4\left(160^{\circ} \mathrm{E}-150^{\circ} \mathrm{W}, 5^{\circ} \mathrm{S}-5^{\circ} \mathrm{N}\right)\right)$ with the observed temperature from Nigeria and the temperature is further compared with the associated rainfall. The results show that an increase or decrease in the Niño 3 and Niño 4 SST is accompanied by a corresponding change in the temperature over Nigeria; however, there is better agreement with the Niño 3 SST compared to the Niño 4 SST. The investigation suggests that a slight northward (southward) shift in the mean position of Intertropical Convergence Zone (ITCZ) during a La Niña (El Niño) event is followed by a reduction (increase) in the average temperature within Nigeria while the mean precipitation rises (reduces) over the country. These results could aid weather prediction which might improve the economy as well as save lives and property during climate-related hazards like drought, forest fires and floods.
\end{abstract}

Keywords: El Niño; La Niña; ENSO; precipitation; temperature; Niño 3 SST; Niño 4 SST

\section{Introduction}

El Niño Southern-Oscillation (ENSO) refers to the cycle of coherent and sometimes very strong variations in the sea surface temperature (SST), convective rainfall, surface pressure and atmospheric circulation across the equatorial Pacific Ocean [1-3]. The pattern generally fluctuates between two states called La Niña (cold phase) and El Niño (warm phase). The warm phase is associated with reduced rainfall in the Western Equatorial Pacific and prolonged warming with higher precipitation in the Eastern Equatorial Pacific (EEP) when compared with neutral condition, while the patterns are reverse during La Niña event [4]. ENSO episodes are usually identified with changes in the Niño $3\left(150^{\circ} \mathrm{W}-90^{\circ} \mathrm{W}, 5^{\circ} \mathrm{S}-5^{\circ} \mathrm{N}\right.$ ) (or Niño $3.4\left(170^{\circ} \mathrm{W}-120^{\circ} \mathrm{W}, 5^{\circ} \mathrm{S}-5^{\circ} \mathrm{N}\right)$ ) anomalies, which correspond to the departure in the monthly SST from its long-term mean over the Niño 3 (or Niño 3.4) region of the EEP [5]. Details of the underlying mechanisms of ENSO event have been reported in many studies [3,6-11].

Though an ENSO event originates within the Tropical Pacific Ocean, it affects climate worldwide through atmospheric teleconnections [1-3]. For instance, the events are a strong determinant of interannual climate variability in many African countries, affecting weather conditions and farming activities. A strong La Niña event is characterized by flooding in the Southern part of Africa, while there is severe drought in East Africa (Figure 1). However, these conditions are reversed during an 
El Niño episode, such that a drier than normal condition will prevail over Southern Africa, while the East will be under intense flood (Figure 1b). Hence, there will be El Niño-induced low farm yield in Southern Africa but the productivity from suitable crops during the extended rainy season in Uganda increases [11,12]. Despite the strong impacts of the event on global climate and the resulting intensification of research to understand ENSO characteristics, little is known about the effects of the events in Nigeria, especially on the temperature and rainfall patterns, which are important for the agricultural sector and the Nigerian economy as a whole. Hence, the aim of this study is to investigate the effects of changes in ENSO characteristics on the background temperature and precipitation in Nigeria.

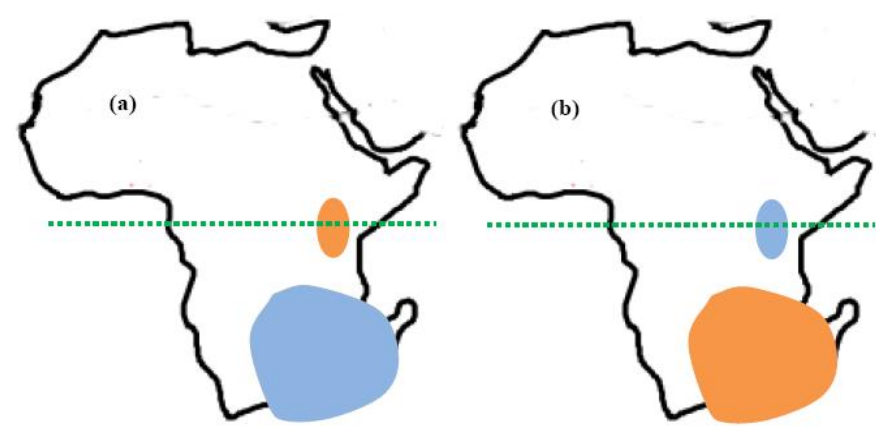

Figure 1. The schematic representation of (a) La Niña and (b) El Niño conditions over Africa. The light-blue areas are the wet and cool conditions, while the orange color stands for the dry and warm regions; the green broken line is the Equator.

\section{The Study Area}

The study area is Nigeria with focus on Abuja, the country's capital located in the Central region, the southern part include Port-Harcourt and Ikeja while Sokoto and Maiduguri represent the northern area (Figure 2). Nigeria is a tropical country in West Africa, positioned approximately between latitudes $4^{\circ} \mathrm{N}$ and $14^{\circ} \mathrm{N}$ and within longitudes $3^{\circ} \mathrm{E}$ and $14^{\circ} \mathrm{E}$ along its widest borders and occupies total area of about $923,768 \mathrm{~km}^{2}$ (2012 estimate) [13]. The country is a strategic place for investors and many businesses due to its abundant natural resources (led by petroleum) and population of over 174 million people (2012 estimate) [13]. Apart from oil trade, one major occupation of the people is farming and it depends strongly on weather pattern. Geographically, Nigeria is bounded in the North by Niger Republic, West by Benin Republic and shares boundary with Cameroon in the East. The southern part is occupied by Atlantic Ocean, where the Ikeja port in Lagos State is located; it is the leading port in Nigeria and one of the largest and busiest in Africa.

As a tropical region, it is warm throughout the year in Nigeria. The temperature rises as the Sun crosses the Equator and moves northward in March, thus leading to the highest temperature around March in Nigeria. For instance, the daily temperature range could go beyond $35-38^{\circ} \mathrm{C}$ depending on the location in Nigeria, while the mean monthly value is about $27^{\circ} \mathrm{C}$ [14]. The warming diminishes when the Sun migrates southward, resulting in the secondary high peak in October-November. The country is more wet, damp and humid in the southern part than in the North; the mean rainfall reduces northward over the country (Figure 3). This pattern is, however, affected by the seasonal changes in rainfall, which in turn is important for farming activities. In general, the dry season is between November and March (October-April) in the South (North) while the remaining months are in wet season. These seasonal patterns occur because the country's climate is influenced by two air masses, the cool, moisture bearing southwestern wind from the Atlantic Ocean and the hot, dry north-easterlies continental air mass from the Sahara desert. The Inter-Tropical Convergence Zone (ITCZ) is the interface between the two air masses; it is a band of clouds and rainfall with occasional 
thunderstorms (Figure 4). The location of the ITCZ controls the seasonal distribution of the rainfall and the length of the net season.

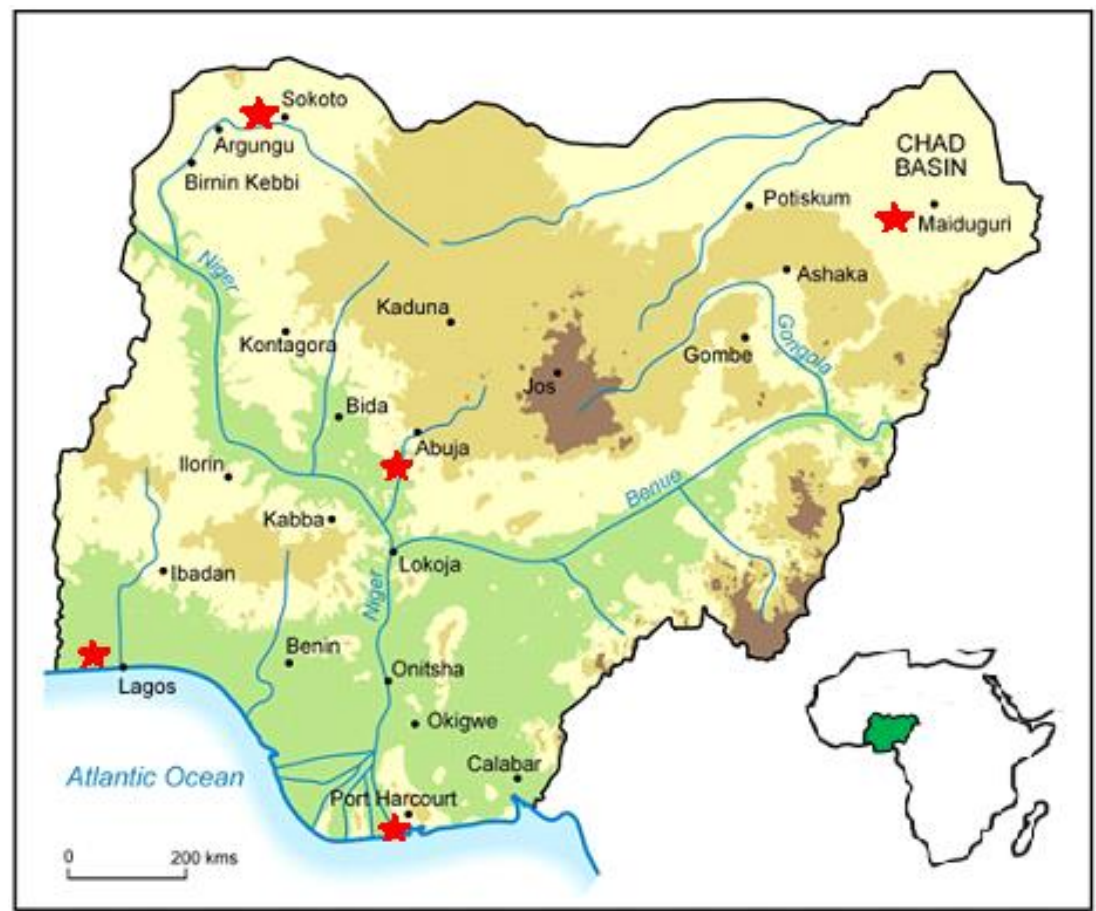

Figure 2. Map of Nigeria showing the study areas (marked with red stars) (Adapted from Adelana et al., 2008; [15] ). Inserted is the map of Africa with location of Nigeria in green.

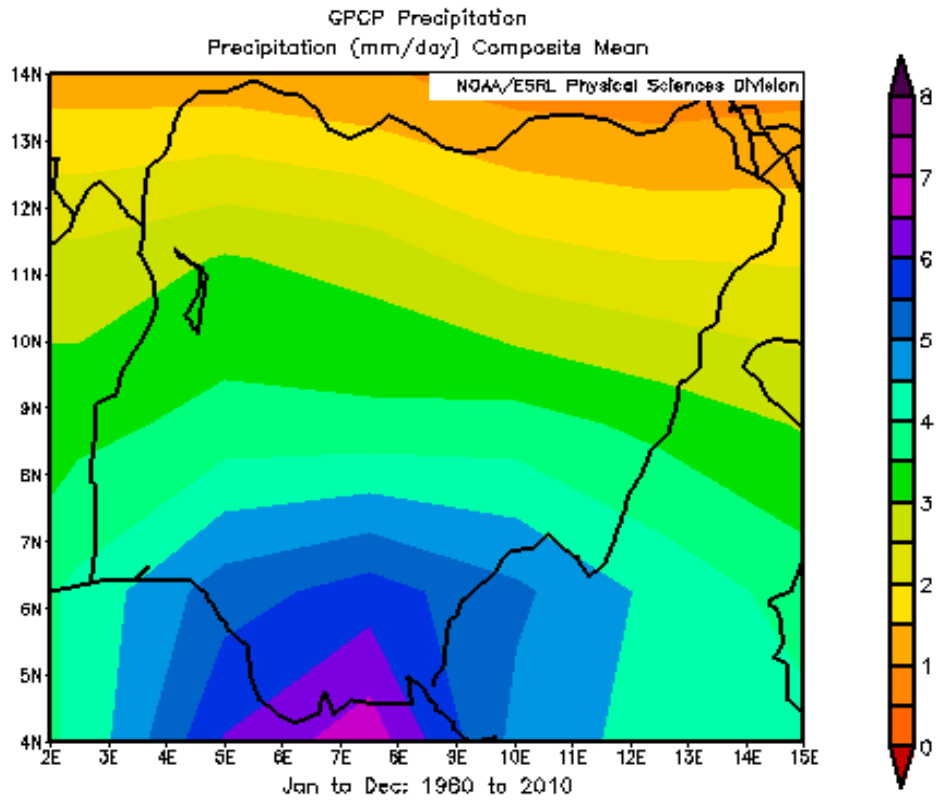

Figure 3. The distribution of the total annual rainfall (in $\mathrm{mm} /$ day) over Nigeria, averaged within 1980 to 2010 (source: Global Precipitation Climatology Project (GPCP), monthly precipitation data www.esrl.noaa.gov/psd/cgi-bin/data/composites/printpage.pl). 


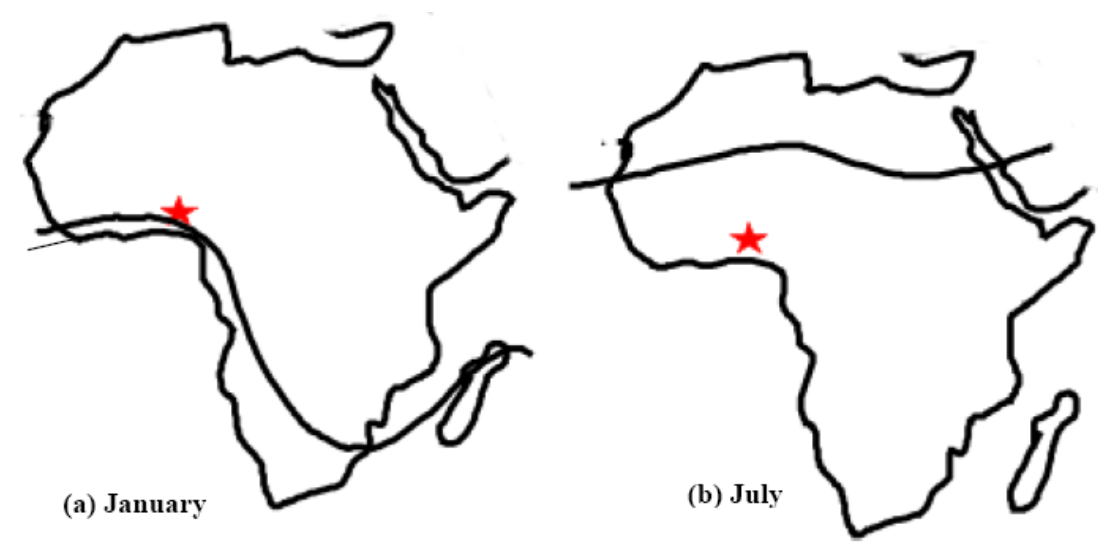

Figure 4. The maps of Africa showing the locations of the ITCZ in (a) January and (b) in July. The approximate locations of Nigeria on the maps are marked with red stars.

The ITCZ is in the southernmost location within January-February (Figure 4a), during which dry season sets in over Nigeria under the influence of the northeast winds, while there is long rainy season between March-July as the ITCZ moves northward. The precipitation is reduced in July-August, during which the ITCZ is in the northern-most position (Figure $4 \mathrm{~b}$ ). This is followed by a short rainy season as the ITCZ migrates southward around September-October, after which the long dry season prevails while rainy season covers June to September in the region due to the ITCZ's presence. Hence, temperature is generally low in the South, which is near the Atlantic Ocean, and high in the North, which is usually dry and cloud free in most periods of the year. The variations in the temperature and rainfall follow the North-South migration of the Sun and the shift in the ITCZ position. Food production in sub-Saharan Africa is climate dependent; hence crops are planted in Nigeria according to the season of the year when enough moisture is available to sustain plant growth and maximum yield.

For instance, an El Niño induced drought in Nigeria had been reported by some studies [16] while cases of more forest fires and low crop yields had been found [17]. However, despite the wide range of studies on the impacts of ENSO on global climate, little is known about the effects of the event on temperature and rainfall distribution in Nigeria. More work is therefore needed to support our ability to accurately predict ENSO characteristics, which may be a useful tool needed by Nigerian planning authorities for advance responses to be developed. Hence, the objective of this work is to investigate the impacts of ENSO on Nigerian climate using temperature and rainfall data from different zones of the country. The choice of the zones is necessary since data representing Nigeria as a whole was not immediately available for analysis. The findings will improve our understanding of the links between the changes in the background temperature from the ENSO region of the Tropical Pacific Ocean and the observed temperature and rainfall patterns in Nigeria. This is important so as to improve the accuracy of climate prediction which could save lives and properties during the ENSO related hazards in Nigeria.

\section{Data Description}

The data used in this study include the observed monthly temperature and monthly precipitation from different regions of the country with Abuja in the middle, Port-Harcourt and Ikeja in the South, and Sokoto and Maiduguri in the North. The temperature values from Nigeria are compared with the SST from the ENSO regions of the Tropical Pacific. This is necessary since SST is the main indicator of an El Niño (La Niña) event that raises (reduces) the magnitude of rainfall over the Niño 3 region during an ENSO episode. The available data are part of the National Metrological Agency (NIMET) observational records that cover 1980 to 2010; the exception is Abuja, where values from 1983 to 2010 are used due to insufficient data in 1980-1982. The whole data range is used in this study since many important ENSO events took place during the period. For instance, one of the strongest El Niño events 
on record occurred in 1982/1983, while the longest episode of 1990-1995 [18] and that of 1997/1998, which belong to one of the strongest in history [19], happened within the time used in this investigation. The period also covered the 2002/2003, 2004/2005 and the 2009/2010 El Niño events [20].

Similarly, the La Niña event that formed in late 1983-1985, the relatively strong episode of $1988 / 1989$, the 1995/1996 weak event, the strong one of 1998/1999 that extended to the year 2001 and the moderate event between 2007 and 2009 [21,22] are within the analyzed period. The temperature is estimated as the mean value $\left[\frac{1}{2}\right.$ (maximum temperature + minimum temperature $\left.)\right]$ from the selected regions while the overall monthly mean of both temperature and precipitation are also calculated for each location. However, some months are without data; a problem that could affect part of the conclusions drawn from this work. The temperature values from Nigeria are compared with the SST and precipitation from the Niño $3\left(150^{\circ} \mathrm{W}-90^{\circ} \mathrm{W}, 5^{\circ} \mathrm{S}-5^{\circ} \mathrm{N}\right)$ and Niño $4\left(160^{\circ} \mathrm{E}-150^{\circ} \mathrm{W}, 5^{\circ} \mathrm{S}-5^{\circ} \mathrm{N}\right)$ regions of the Tropical Pacific; these locations are important for understanding ENSO characteristics. However, of major importance in ENSO development is the Niño 3 region, which is more sensitive to temperature changes during cold and warm events, while the Niño 4 is included to test the link between this region and the climate of Nigeria. The Niño 3 data and Niño 4 SST used in the study were obtained from the website of the Climate Prediction Center of the National Oceanic and Atmospheric Administration (NOAA); the data are available on www.esrl.noaa.gov/psd/data/climateindices/list. Similarly, we compared rainfall from Nigeria with that from the NOAA Global Precipitation Climatology Project (GPCP) monthly precipitation data (1994-2000) $\left(\mathrm{mmday}^{-1}\right)$ [23] obtained from their website at www.esrl.noaa.gov/psd/data/gridded/tables/monthly.html and at www.esrl.noaa.gov/psd/cgi-bin/data/composites/printpage.pl.

\section{Results}

\subsection{The Variations in the SST and Temperature}

The monthly long term mean of the SST from the Niño 3 and Niño 4 boxes are compared with the monthly long term mean temperature from Nigeria so as to establish the possible link between the mean states of the ENSO regions and Nigeria (Figure 5). The SSTs are in good agreement with the temperature pattern from Nigeria; but better match is seen with the Niño 3 SST than with the Niño 4 SST. This is supported by the stronger correlations of $0.83,0.54,0.73,0.58$ and 0.74 between the Niño 3 SST and the respective temperatures from Abuja, Ikeja, Sokoto, Maiduguri and Port-Harcourt when compared with the corresponding values of $-0.59,-0.78,0.31,0.54$ and -0.67 from the Niño 4 box. The correlations indicate that a rising Niño 3 SST will increase the temperature over Nigeria while negative correlation from Niño 4 box suggests that the warming reduces in Nigeria as the SST intensifies in the Niño 4 region; these are attributes of La Niña event. The magnitudes of the Niño 3 SSTs are lower than those recorded within Nigeria since the temperatures were measured over land while the high values in Niño 4 region were estimated over the warm pool. The observed patterns are also in agreement with the Niño 3 and Niño 4 SSTs obtained in the pre-industrial simulation from Kiel Climate Model [3]. Thus, the agreement with the SST shows that there is good link between the mean climate in Nigeria and that from the ENSO regions.

Furthermore, the results indicate that the mean temperature is generally low in January and August in all the selected areas but the highest temperature is obtained in the North with the peak values diminishing southward, as depicted in Figure 5. The temperatures in December-February are slightly higher in the central-southern locations compared to the North, while the situation is reversed in August. The temperature intensifies as the Sun crosses the Equator around March and moves northward, leading to the peak intensity in March from the southern regions which shift to April-May in the North with increased magnitudes which have the highest value in Sokoto. The secondary peak in October-November occurred as the Sun returns southward while, the lowest temperature is seen between July and September in southern Nigeria under the moisture bearing cool wind from Atlantic Ocean. 


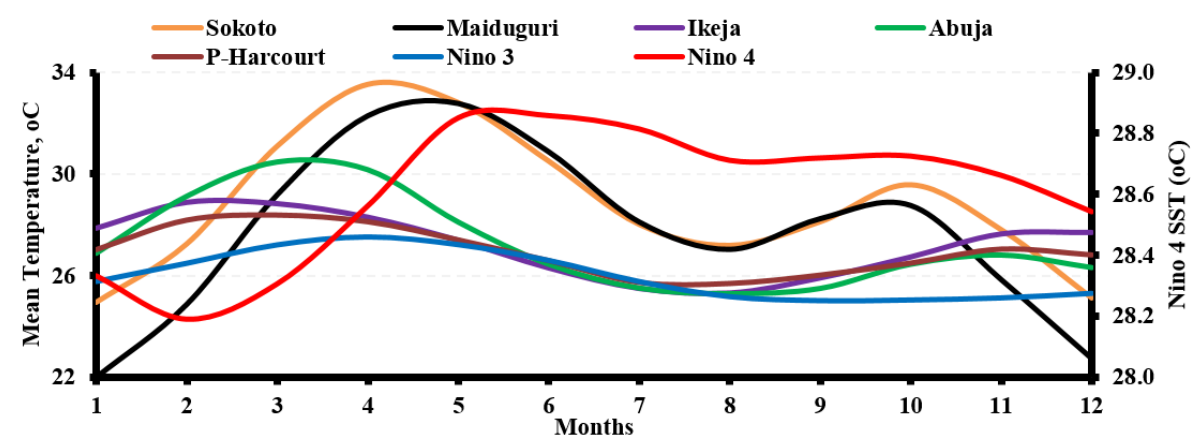

Figure 5. The comparisons between long-term monthly mean temperature and SST $\left({ }^{\circ} \mathrm{C}\right)$ averaged over 1980-2010 (1983-2010 for Abuja). The color codes are as follows: Niño 3 (blue), Niño 4 (red), Ikeja (purple), Port-Harcourt (brown), Abuja (green), Sokoto (orange) and Maiduguri (black).

\subsection{Comparisons of the Temperature and SST Anomalies}

Investigation using anomalies of the SST and temperature is done so as to be able to compare the climate variations from the study area with ENSO events. The anomalies are obtained by subtracting the mean values, averaged over 1980-2010 (1983-2010 for Abuja) from the monthly records; the results are shown in Figure 6. According to the US (United States) NOAA definition, an El Niño (La Niña) event occurs when consecutive three months running mean of the Niño 3 SST anomaly, SSTA, is above +0.5 (below -0.5), while some other reports put it at seven months long warming (cooling) of the Niño 3 region [24]. In this work, the peaks of the temperature anomalies from the different locations are in good agreement with the SSTA from the Niño 3 and Niño 4 regions; however, the matches are better with the Niño 3 SSTA than with the Niño 4 SSTA, which has the peak value around May-June (Figure 6). The peaks of the temperature anomalies are seen in February-March from the South-Central Nigeria, while it occurred in April in the North. The temperature anomalies are low and negative in August, followed by small positive peaks in October (November) from the North (South) with the exception of Ikeja, which stays negative from June till December. In addition, negative anomalies are seen between November and February in the northern regions.

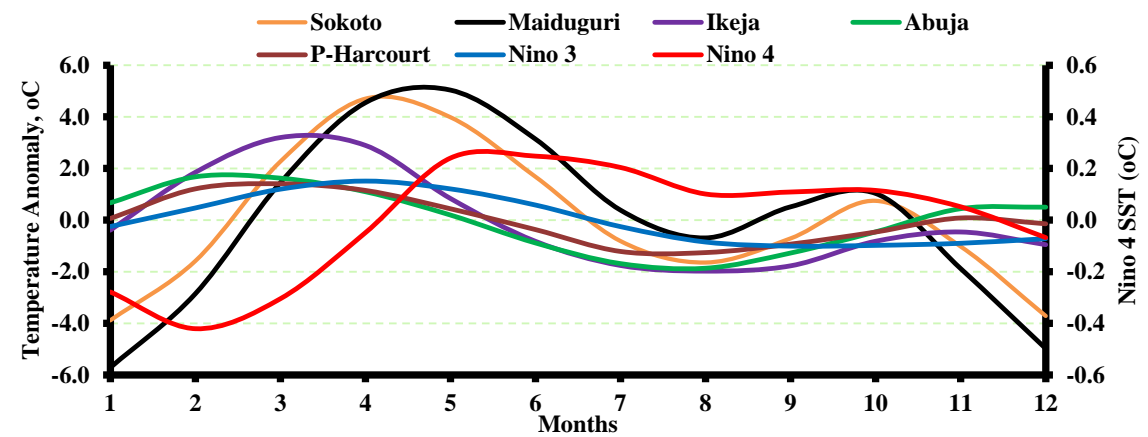

Figure 6. The anomalies of the monthly mean temperature averaged over 1980-2010 (1983-2010 for Abuja). Color codes are the same as in Figure 5.

\subsection{Comparison of the Results with ENSO Events}

The comparison of the mean temperature and the mean rainfall from the study areas in Nigeria with ENSO events is done to further establish the links between ENSO characteristics and the climate patterns in the country. Several ENSO events were considered in pairs to understand the changes in the temperature $\left(\mathrm{T},{ }^{\circ} \mathrm{C}\right)$ and the corresponding Rainfall $(\mathrm{R}, \mathrm{mm})$ during El Niño and La Nina episodes (Figure 7). 
(a)

TEMPERATURE ("C)

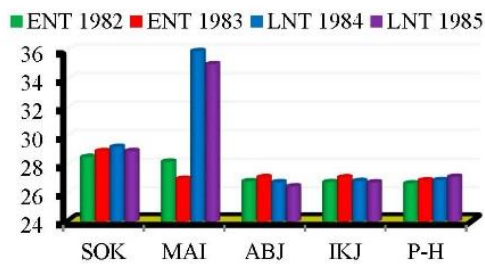

๓ENT 1986 =ENT 1987 - LNT 1988 - LNT 1989

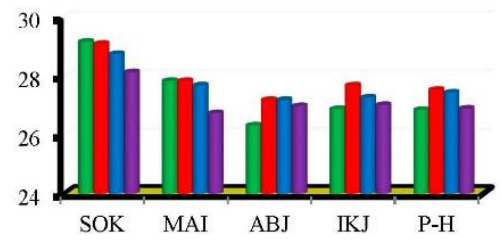

—ENT 1997 —ENT 1998 —LNT 1995 =LNT 1996

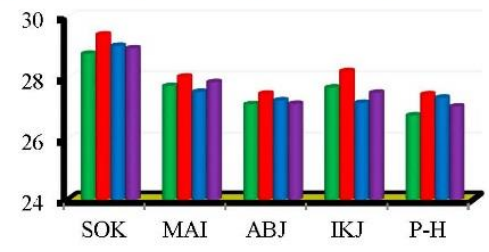

ENT $2002=$ ENT $2003=$ LNT $1999=$ LNT 2000

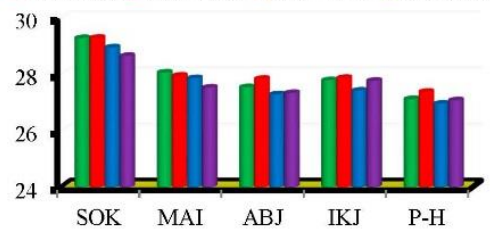

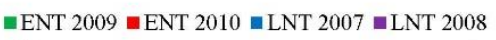

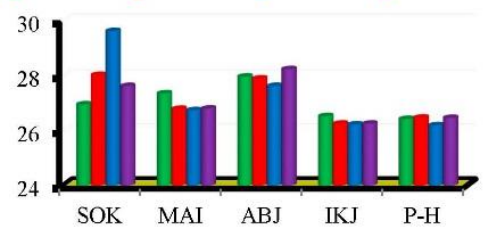

(b)

RAINFALL (mm)

=ENR 1982 =ENR 1983 =LNR 1984 =LNR 1985

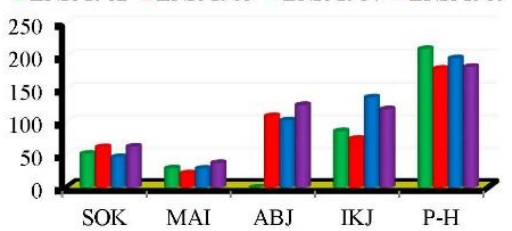

"ENR 1986 =ENR 1987 ㄴ. LNR 1988 =LNR 1989

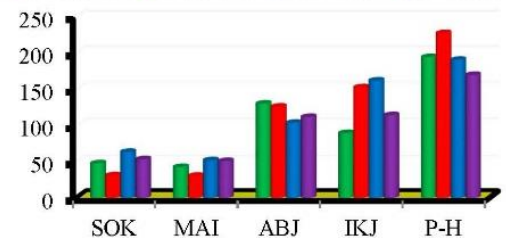

=ENR 1997 =ENR 1998 =LNR 1995 = LNR 1996

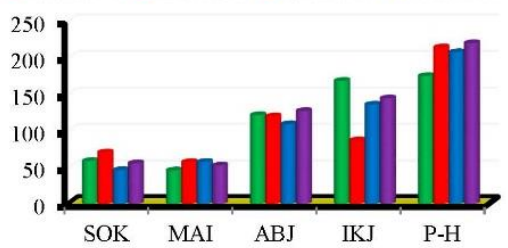

๓ENR 2002 =ENR 2003 =LNR 1999 =LNR 2000

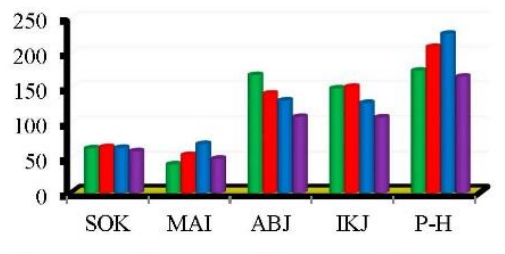

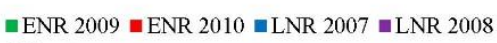

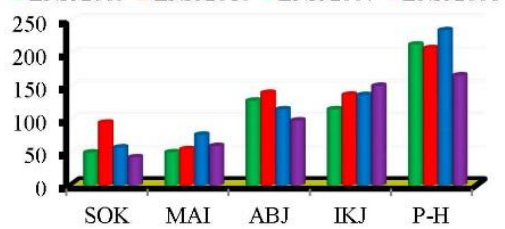

Figure 7. The bar charts of the (a) monthly mean temperature $\left(\mathrm{T},{ }^{\circ} \mathrm{C}\right)$ and $(\mathrm{b})$ Rainfall $(\mathrm{R}, \mathrm{mm} /$ day) during some El Niño and La Niña events. The values covered 1980-2010 (1983-2010 for Abuja). ENT, LNT are El Niño, La Niña Temperatures respectively, while ENR, LNR are the respective El Niño, La Niña Rainfall values. Names of the study areas are shown in short forms on X-axis.

The warm events that started in 1982, 1986, 1997, 2002 and 2009 together with the La Niña episodes from 1984, 1988, 1995, 1999 and 2007 were considered along with the years following the beginning of the events. Under temperature, the figures show that an El Niño occurrence leads to high temperature in the year following the event while the temperature is reduced in the year after a La Niña condition (Figure 7). Further investigation indicates that an El Niño phase will lead to high temperature in the following spring and summer months after the event while the spring and summer temperatures are reduced after a La Niña condition (not shown). Therefore, the strong El Niño condition of 1997/1998 might explain the rise in the overall mean temperature of 1998, which is also higher in all the study locations than the values recorded in 1997, during which the warm event was at the peak (Figure 7). Conversely, the 1988/1989 strong La Niña event is followed by reduction in the mean temperature in 1989 over Nigeria compared to 1988. Considering the rainfall, the intensities of the mean rainfall are generally lower in an El Niño years than the magnitudes in the year after a strong event while the rainfall becomes more during a La Niña occurrence but the strength reduces after the cold event. 
The overall results indicate that the mean temperature over the entire country is higher (lower) after an El Niño (a La Niña) year compared to the magnitude during a strong El Niño (La Niña) event, while the rainfall is stronger during a La Niña case than in the El Niño period. The impacts on the temperature and rainfall rise with the strength of both events. However, there are some exceptions to the above conclusions that might be due to missing or insufficient data in some years from the study locations. The rainfall patterns also suggest that the peak period, December-February, of an El Niño (La Niña) condition is associated with an overall decrease (increase) in the mean precipitation over Nigeria (not shown). In an El Niño year, the reduction in the mean precipitation is strongest in the northern Nigeria when compared to the South. The low magnitude of the rainfall over the country is due to the ITCZ position which shifts more slightly to the South (beyond the mean southern extreme) at the time of an El Niño. Investigation with some ENSO events suggests that the rainfall pattern in El Niño years show good agreement with the southward shift in the ITCZ location-as indicated by the region with the peak rainfall (pink-purple-blue color) (Figure 8a-c for 1982/1983, $1986 / 1987$, and 2002/2003, respectively). However, less drought is expected as the intensity of the rainfall rises over the country in a La Niña year due to the northward spread of the rainfall along with the regions of the strongest precipitation which represent the ITCZ location (Figure 8d-f for 1984/1985, 1995/1996, and 2007/2008, respectively). Further study using the rainfall patterns over the Tropical Pacific suggests that the above changes in the ITCZ position and the rainfall in Nigeria is caused by southward (northward) movement of the ITCZ location over the Tropical Pacific during an El Niño (La Niña) episode (Figure 8g-i for El Niño; Figure 8j-1 for La Niña).

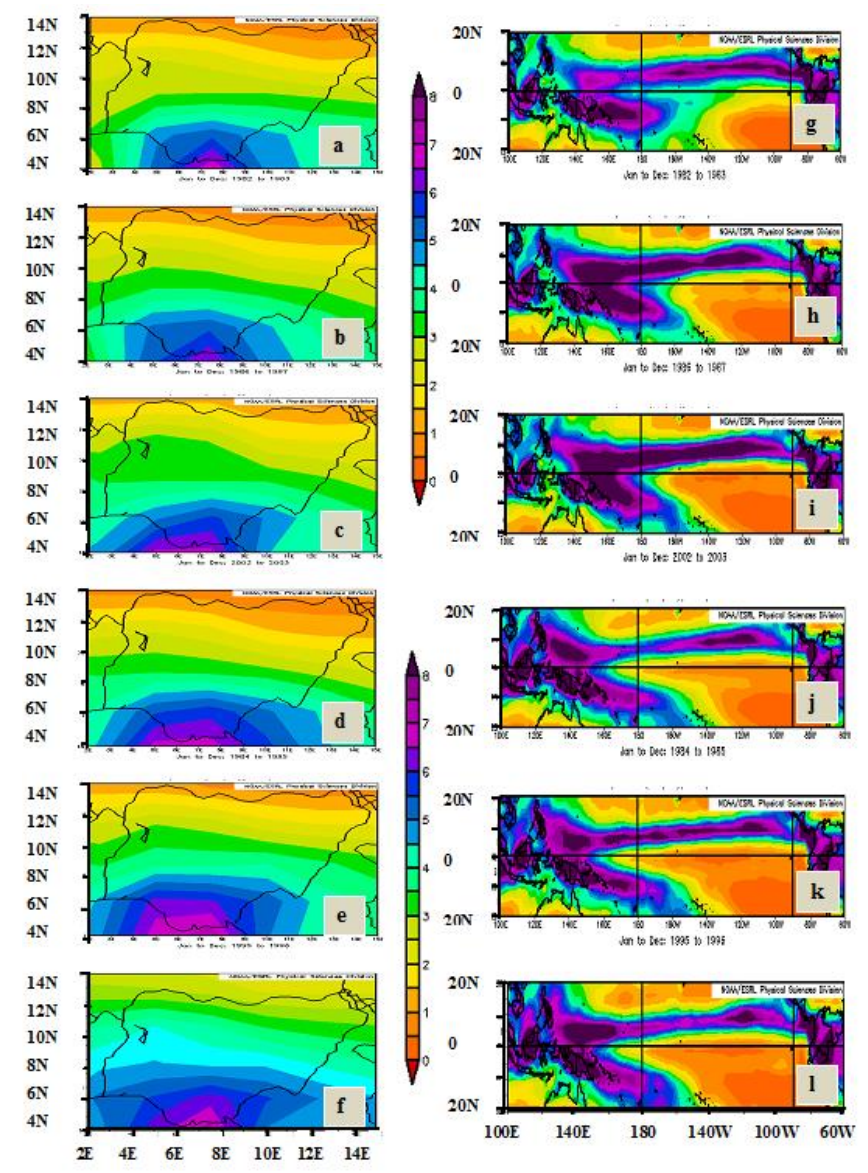

Figure 8. El Niño Episodes and La Niña Episodes: The rainfall patterns during El Niño episodes of (a) 1982/1983, (b) 1986/1987, and (c) 2002/2003; and La Niña cases of (d) 1984/1985, (e) 1995/1996, and (f) 2007/2008; and (g-1) the respective rainfall patterns over the Tropical Pacific (both sets of maps are on the same scale). (source: www.esrl.noaa.gov/psd/cgi-bin/data/composites/printpage.pl). 
In addition, the comparison between the El Niño events (Figure 8g-i) and the La Niña cases (Figure 8j-1) show southward spread of the ITCZ location and the associated rainfall during an El Niño episodes when compared with the La Niña years during which the ITCZ width becomes thin and stays in the far North. Hence, the increase in the rainfall above the background mean during a La Niña year is strongest in the southern Nigeria and reduces northward. The highest values are observed in Port-Harcourt followed by Ikeja, Lagos (South) with slight increase in Abuja (central) while almost none is seen in the North. The rainfall patterns also have broader bases and maintained moderate levels in all locations in Nigeria during La Niña events (e.g., 1988 and 1999) compared to El Niño periods (1997) (not shown), thus suggesting that the rain starts early during La Niña year and spreads over several months of the year, especially in the South. Though the least rainfall is recorded in December-January across Nigeria, the small increase in the precipitation within the southern-central regions at the time of La Niña, supports a slight northward shift of the mean ITCZ position during the period when compared to neutral condition. The overall results suggest that the magnitude of the average rainfall in Nigeria is low (high) during an El Niño (a La Niña) event (Figure 7).

\section{Discussion of the Results}

The results show that there is good connection between ENSO events and the changes in the background temperature and the precipitation in Nigeria. The investigation suggests that the major link between an ENSO event and changes in the temperature and precipitation patterns in Nigeria is associated with variations in the ITCZ position. This is such that an El Niño induced southward shift in the ITCZ mean position is accompanying by reduction in the intensity of the overall rainfall in the country while the corresponding mean temperature after an El Niño event will be on the rise under the resulting clear sky. Furthermore, a slight northward shift of the ITCZ position during a La Niña event will lead to a northward spread in the intensity of the rainfall under a more cloudy condition and an increase (reduction) in the total intensity of the precipitation (temperature).

An investigation to ascertain the main cause of changes in the temperature is done by comparing the temperature with the observed solar radiation from all the locations and the effects on the rainfall (Figure 9). The Gunn-Bellani radiation data (in millimeters) that relates the volume of liquid distilled by solar radiation to the quantity of solar radiation reaching a horizontal surface is used for the comparison [25]. The Gunn-Bellani data is converted to solar radiation intensity unit of $\mathrm{MJm}^{-2}$. day ${ }^{-1}$ (Millijoules per meter square per day) by multiplying the values with a factor of 1.216 proposed by Ododo [26]. For each location, the mean temperature increases with rising insolation while the resulting increase in the precipitation is highest among the three variables. According to the figure, the magnitude of the insolation forcing and the induced temperature is higher in the North than in the southern Nigeria. However, the intensity of the corresponding precipitation increases southward with the least in Maiduguri and the highest in Port-Harcourt where the impact of moisture bearing southwestern winds from the Atlantic Ocean and the ITCZ is highest.

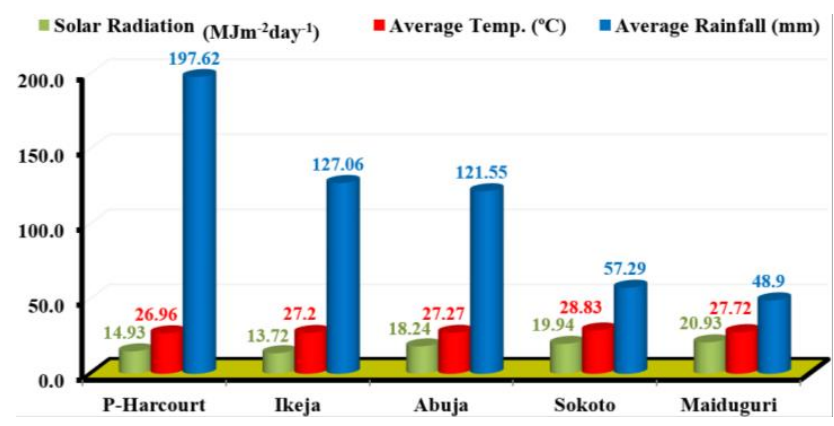

Figure 9. The comparisons between mean insolation forcing, mean temperature and mean precipitation averaged over 1980-2010 for all the study locations in Nigeria; the exception is Abuja with the mean values between 1983-2010 due to insufficient data in 1980-1982. 
The mean temperature and precipitation, averaged over 1980-2010 (1983-2010 for Abuja), are also compared. Overall, the investigation shows a linear relationship between the solar radiation and the induced temperature, thus indicating that the observed variations in the temperature are mainly controlled by the insolation forcing (Figure 10a). The result is also in agreement with the pre-industrial simulation reported from Kiel Climate Model in which linear variation was observed between the top of atmosphere insolation forcing and the resulting temperature [3]. However, both the insolation forcing and the induced temperature are lowered in the southern Nigeria under the impacts of the precipitation and the associated cloud which are higher in the region than in the northern part of the country (Figure 10b). In agreement with the above findings, the results indicate that the temperature decreases with increasing precipitation; it shows a better fit when compared with solar radiation (Figure 10a). It further suggests that the variations in the intensities of the rainfall are more important in shaping the temperature patterns over Nigeria (Figure 10). In addition, this weakening effect of rainfall on temperature might further explain the better agreement between the Niño 3 SST and the magnitude of the temperature from the southern Nigeria; this is unlike the northern Nigeria where the reduction under the precipitation is low.

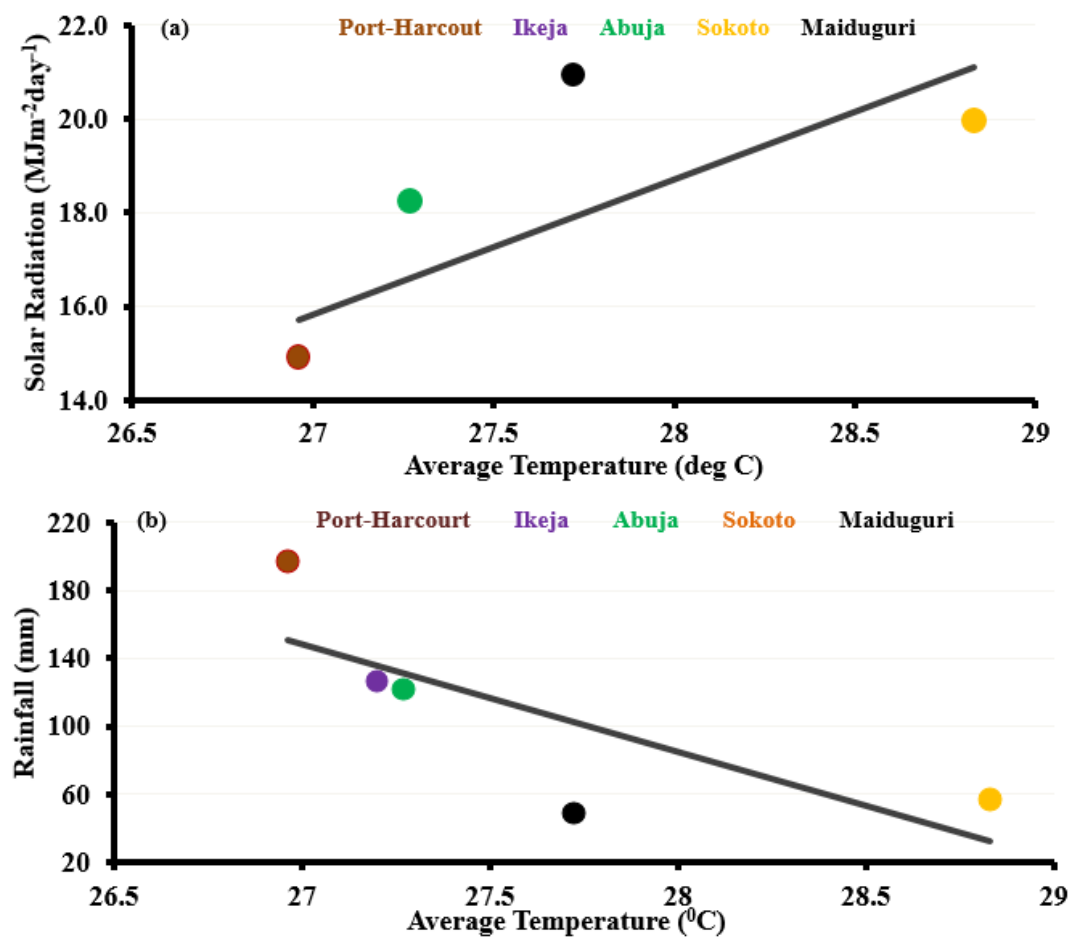

Figure 10. The plots of monthly mean (a) solar radiation against that of temperature $\left({ }^{\circ} \mathrm{C}\right)$ and (b) monthly mean rainfall $(\mathrm{mm})$ against that of temperature $\left({ }^{\circ} \mathrm{C}\right)$; the values are averaged over 1980-2010 (1983-2010 for Abuja). The color code for each location is the same as in Figure 5.

\section{Conclusions}

The temperatures observed from the different locations within Nigeria between 1980 and 2010 (1983-2010 for Abuja) are compared with the SST from the Niño 3 and Niño 4 regions of the Tropical Pacific while a further comparison of the temperature with the rainfall in Nigeria is also done. This is necessary so as to establish the connections between an ENSO event and the climate patterns in Nigeria. The outcome shows good link between the ENSO events and the Nigerian climate with the strongest agreement coming from the Niño 3 region of the Tropical Pacific. The finding indicates that the primary driver of climate like the south-westerlies that brings monsoon into the country from South Atlantic Ocean, the north-easterlies that lead to Tropical dry climate in the North and the 
ITCZ, which is sandwiched between the air masses, could be affected by changes in ENSO events. According to the results, the major link between an ENSO event and changes in the temperature and rainfall in Nigeria is associated with shifts in the ITCZ position. An El Niño (La Niña) induced southward (northward) shift in the ITCZ mean position is accompanying by reduction (increase) in the intensity of the mean rainfall in the country while the corresponding mean temperature after an El Niño (La Niña) event will rise (reduce). This is similar to other studies where El Niño induced drought have been reported in Nigeria [16].

In terms of economic activities, the low rainfall in El Niño years and the associated drought will allow businesses to go on with less interruptions from heavy rainfall across the country. For instance, smooth running of oil exploration will be possible due to less rainfall and reduced stormy weather conditions. However, the El Niño induced high temperature along with low rainfall could raise the cases of bush burning, deforestation, environmental degradation and ultimately cause low crop yields with less income for Nigerian farmers. On the other hand, these conditions are reversed during a La Niña induced increase in the precipitation level. Though high intensity of rainfall might lead to flooding that could render many people homeless and paralyze businesses, but moderately high rainfall will reduce environmental hazards from bush burning, favor crop yields and increase farmer's income through crop sales while an overall improvement in economy will raise the standard of living of the people.

Conclusively, the impacts of ENSO cannot be over-looked in Nigeria and also in many parts of the world. These findings might be very helpful for re-designing seasonal agriculture, road construction, management of flood and water resources in Nigeria and probably in the surrounding countries. Hence, there is need for sensitization of the farmers on ENSO and the government on the possible interventions before and during the associated climate problems. We could also improve crop yield by planting appropriate crops like drought resistant types during low rainfall, by reliable forecast of ENSO events and the associated temperature and precipitation in Nigeria. However, more research is required to further improve our understanding of the impacts of ENSO on other regions or countries, especially in Africa where the negative impacts of ENSO could be very costly and difficult to bear.

Acknowledgments: The authors wish to express their profound appreciation to the National Metrological Agency (NIMET) of Nigeria for making the data of Nigeria available. In addition, many thanks to NOAA/OAR/ESRL PSD, Boulder, Colorado, USA for the Niño 3 and Niño 4 SST data obtained from Climate Prediction Center on their website at www.esrl.noaa.gov/psd/data/climateindices/list and for the NOAA Global Precipitation Climatology Project (GPCP) monthly precipitation data (1994-2000) obtained from their website at www.esrl.noaa.gov/psd/data/gridded/tables/monthly.html and at www.esrl.noaa.gov/psd/cgi-bin/data/composites/printpage.pl. Similarly, the authors appreciate the efforts and suggestions of the reviewers which had improved the manuscript.

Author Contributions: The data were analyzed and put together into paper by Opeyemi R. Salau with support from Ayodele Fasuba, while Kelvin A. Aduloju, Gbenga E. Adesakin and Adetona T. Fatigun contributed substantially to the scientific part of the study.

Conflicts of Interest: The authors declare no conflict of interest.

\section{References}

1. Chavez, F.P.; Strutton, P.G.; Friederich, G.E.; Feely, R.A.; Feldman, G.C.; Foley, D.G.; McPhaden, M.J. Biological and chemical response of the Equatorial Pacific Ocean to the 1997-98 El Niño. Science 1999, 286, 2126-2131. [CrossRef] [PubMed]

2. McPhaden, M.J.; Busalacchi, A.J.; Cheney, R.; Donguy, J.R.; Gage, K.S.; Halpern, D.; Ji, M.; Julian, P.; Meyers, G.; Mitchum, G.T.; et al. The tropical Ocean Global Atmosphere observing system: A decade of progress. J. Geophys. Res. 1998, 103, 14169-14240. [CrossRef]

3. Salau, O.R.; Schneider, B.; Park, W.; Khon, V.; Latif, M. Modeling the ENSO impact of orbitally induced mean state climate changes. J. Geophys. Res. 2012, 117. [CrossRef]

4. Collins, M.; An, S.-I.; Cai, W.; Ganachaud, A.; Guilyardi, E.; Jin, F.-F.; Jochum, M.; Lengaigne, M.; Power, S.; Timmermann, A.; et al. The impact of global warming on the tropical Pacific Ocean and El Niño. Nat. Geosci. 2010, 3, 391-397. [CrossRef] 
5. Latif, M.; Keenlyside, N.S. El Niño/Southern Oscillation response to global warming. Proc. Natl. Acad. Sci. USA 2009, 106, 20578-20583. [CrossRef] [PubMed]

6. Philander, S.G.H. El Niño, La Niña, and the Southern Oscillation; Academic Publishing: London, UK, 1990.

7. Neelin, J.D.; Battisti, D.S.; Hirst, A.C.; Jin, F.F.; Wakata, Y.; Yamagata, T.; Zebiak, S.E. ENSO theory. J. Geophys. Res. Oceans 1998, 103, 14261-14290. [CrossRef]

8. Wang, C.; Picaut, J. Understanding ENSO physics-A review. In Earth's Climate: The Ocean-Atmosphere Interaction; AGU: Washington, DC, USA, 2004; pp. 21-48.

9. Eckert, C.; Latif, M. Predictability of a stochastically forced hybrid coupled model of El Niño. J. Clim. 1997, 10, 1488-1504. [CrossRef]

10. Fedorov, A.V.; Philander, S.G. Is El Niño changing? Science 2000, 288, 1997-2002. [CrossRef] [PubMed]

11. Salau, O.R. El Niño, Southern Oscillation during the Holocene and Eemian Warm Periods. Ph.D. Thesis, University of Kiel, Kiel, Germany, 2012.

12. Phillips, J.; McIntyre, B. ENSO and Interannual rainfall Variability in Uganda: Implications for Agricultural Management. Int. J. Climatol. 2000, 20, 171-182. [CrossRef]

13. Worldwide Index, Federal Republic of Nigeria (NG). 2010. Available online: www.tageo.com/ index-e-ni-cities-NG.htm (accessed on 28 August 2015).

14. Eroarome Martin Aregheore (2015), Nigeria, Section 3-Climate and Agro-Ecological Zones Climate. Available online: www.fao.org/ag/agp/agpc/doc/counprof/nigeria/nigeria.htm (accessed on 17 November 2014).

15. Adelana, M.; Olasehinde, P.I.; Bale, R.B.; Vrbka, P.; Goni, I.B.; Edet, A.E. An overview of the geology and hydrogeology of Nigeria. In Applied Groundwater Studies in Africa; Taylor \& Francis: London, UK, 2014; pp. 171-197.

16. Okeke, F.N.; Marengo, J.A.; Nobre, C. Investigation of El Niño and La Niña effects and the impact of Atlantic sea surface temperatures (SSTs), on precipitation in Nigeria from 1950 to 1992. Surv. Geophys. 2006, 27, 545-555. [CrossRef]

17. Olori, T. Environment-Nigeria: El Nino Sets its Sights on Nigeria's Farms, Inter Press Service, IPS. 2015. Available online: www.ipsnews.net/1997/12/environment-nigeria-el-nino-sets-its-sights-on-nigerias-farms / (accessed on 28 August 2015).

18. Trenberth, K.E. The definition of El Niño. Bull. Am. Meteorol. Soc. 1997, 78, 2771-2777. [CrossRef]

19. McPhaden, M.J. Genesis and Evolution of the 1997-98 El Niño. Science 1999, 283, 950-954. [CrossRef] [PubMed]

20. Historical El Niño/ La Niña episodes (1950-present), NOAA's Climate, Prediction Center. 2015. Available online: www.cpc.ncep.noaa.gov/products/analysis_monitoring/ensost (accessed on 10 December 2015).

21. La Niña Information. 2015. Available online: www.publicaffairs.noaa.gov/lanina.html (accessed on 31 July 2015).

22. Cold and Warm Episodes by Season. 2015. Available online: http://www.cpc.noaa.gov/products/ analysis_monitoring/ensostuff/ensoyears.shtm (accessed on 20 August 2015).

23. Adler, R.F.; Huffman, G.J.; Chang, A.; Ferraro, R.; Xie, P.; Janowiak, J.; Rudolf, B.; Schneider, U.; Curtis, S.; Bolvin, D.; et al. The Version 2 Global Precipitation Climatology Project (GPCP) monthly precipitation analysis (1979-present). J. Hydrometeor. 2003, 4, 1147-1167. [CrossRef]

24. Climate Prediction Center. ENSO FAQ: How Often Do El Niño and La Niña Typically Occur? National Centers for Environmental Prediction. Available online: www.cpc.noaa.gov/products/analysis_monitoring/ ensostuff/ensofaq.shtml\#HOWOFTEN (accessed on 10 August 2015).

25. Okonkwo, G.N.; Nwokoye, A.O.C. Estimating global solar radiation from temperature data in minna location. Eur. Sci. J. 2014, 10, 255-264.

26. Ododo, J.C. New models for the prediction of solar radiation in Nigeria. In Proceedings of the 2nd OAU/STRC Conference on New, Renewable and Solar Energies, Bamako, Mali, 16-20 May 1994.

(C) 2016 by the authors; licensee MDPI, Basel, Switzerland. This article is an open access article distributed under the terms and conditions of the Creative Commons by Attribution (CC-BY) license (http:/ / creativecommons.org/licenses/by/4.0/). 